\title{
ÖRGÜTSEL BAĞLAM PARADOKSLARININ GÜÇ OKULU AÇISINDAN DEĞERLENDİRILMESI
}

\author{
Refika BAKOĞLU DELIORMAN ${ }^{1}$, Mukaddes BAHAR ${ }^{2}$ \\ ${ }^{1}$ Marmara Üniversitesi, İ.I.B.F., İşletme Bölümü, Doçent Dr. \\ ${ }^{2}$ Marmara Üniversitesi, S.B.E., Yönetim ve Organizasyon Bilim Dall, Doktora Ögrencisi
}

\section{RETHINKING OF ORGANIZATIONAL CONTEXT PARADOXES ACCORDING TO POWER SCHOOL}

\begin{abstract}
This paper studies strategy process and organizational context in the scope of Power School, and analyses the relationship between strategy processes in organizational context. "Organizational context" refers to the internal dynamics of the organization including organization structure, culture and political issues. In the paper, strategy process in the organizational context is examined in the shadow of two contrasting point of views; Control and Chaos Paradoxes. While Control Paradox affirms that the organizational strategy is determined and executed solely by the leader, Chaos Paradox concludes that the strategy is created within the organization naturally, due to the complex structures in the organization. Considering the two conflicting assertions, it is assumable that Control and Chaos Paradoxes both influence the strategy process, but Chaos Paradox is more closely applicable to organizational strategy process in the scope of new approaches to Power School.
\end{abstract}

Keywords: Power School, Organizational Context, Control Paradox, Chaos Paradox, Organizational Leadership Perspective, Organizational Dynamics Perspective.

\section{GíRiş}

Strateji oluşturma ve uygulama sürecinin en çok cevap aranan sorularından biri "örgüt mü stratejiyi izler, strateji mi örgütü izler?" sorusudur. Bu soruya yanıt verebilmek için örgütsel bağlamın stratejik süreçle olan ilişkisini anlayabilmek önemlidir.

Örgütsel bağlam örgütün iç çevresini işaret etmektedir. Örgütün yapısı, kurum kültürü ve politik bağlam örgütsel bağlamı oluşturmaktadır [1]. De Wit ve Meyer [2] örgütsel bağlamda stratejik sürece iki zıt bakış açısı olduğunu vurgulamaktadır. Bunlar kontrol paradoksu ile kaos paradoksudur. Kontrol paradoksu, stratejik süreci tümüyle liderin ya da üst yönetimin yürüttüğü bir süreç olarak görmektedir. Buna göre lider, bir makinenin tüm kontrolünü elinde tutan kişi gibidir ve önce stratejiyi belirlemekte, ardından örgütün bu stratejiyi uygulamasını sağlamaktadır. Kaos paradoksunu ifade eden görüş ise, örgütün karmaşık etkileşimlerle sürekli değişen kompleks bir sistem olduğunu, stratejinin örgütteki bu karmaşık mekanizmalar içinden geliştiğini

\section{ÖRGÜTSEL BAĞLAM PARADOKSLARININ GÜC OKULU AÇISINDAN DE ĞERLENDIRILMESI}

Özet: Bu çalışma stratejik süreçlerde örgütsel bağlamı güç okulu açısından ele alarak örgütsel bağlamla stratejik süreçler arasındaki ilişsiyi değerlendirmek amacıyla hazırlanmıştır. Örgütün iç çevresi ile ilgili olan örgütsel bağlam; örgütün yapısını, kültürel ve politik özelliklerini ifade etmektedir. Çalışmada stratejik süreçte örgütsel bağlam iki zıt görüşü yansıtan kontrol ve kaos paradoksları açısından ele alınmıştır. Kontrol paradoksu stratejinin lider tarafindan belirlenip uygulamaya konulduğu görüşünü savunurken, kaos paradoksu stratejinin örgütün karmaşılk yapısı sebebiyle örgüt içinden gelişerek ortaya çıktı̆̆ görüşündedir. Bu iki görüş̧ çerçevesinden değerlendirildiğinde stratejik süreçte kontrol ve kaos paradoksunun bütü̈nüyle birbirinden ayrı tutulamayacağ ancak güç okuluna yeni bilimsel yaklaşımlar açısından örgütsel bağlamda stratejik sürecin kaos paradoksu ile daha yakından ilişkili olduğu ileri sürülebilir.

Anahtar Kelimeler: Güç Okulu, Örgütsel Bağlam, Kontrol ve Kaos Paradoksu, Örgütsel Liderlik Perspektifi, Örgütsel Dinamikler Perspektifi.

dolayısıyla böyle bir ortamda liderin strateji oluşumuna çok az etkisinin olabileceğini ileri sürmektedir.

Stratejik süreci açıklamakta gelişmekte olan yaklaşımlardan biri de güç okuludur. Güç okulunun stratejik süreçte güç, politikalar ve koalisyonlar gibi kavramları gündeme getirmesi bakımından, örgütsel bağlam ile güç okulu kavramlarının yakından ilişkili olduğu söylenebilir. Yapılan literatür çalışmasında her iki kavramın ilişkilendirildiği çalışmalarla karşılaşılmadığı noktasından hareketle bu çalışmada stratejik süreç güç okulu açısından ele alınarak, örgütsel bağlamda kontrol ve kaos paradoksu temelinde değerlendirilmeye çalışılacak, böylelikle örgütsel bağlam ile güç okulu arasındaki ilişki irdelenecektir. Çalışmanın ilk bölümünde güç, politikalar ve güç okulu kavramsal olarak incelenecektir. İkinci bölümde örgütsel bağlamda kontrol ve kaos paradoksu açıklanacak, stratejik süreç bu paradokslara dayanan örgütsel liderlik ve örgütsel dinamikler perspektiflerine göre ele alınacaktır. Son bölümde ise güç okulu açısından örgütsel bağlam değerlendirilecektir. 


\section{GÜÇ, POLITTIKALAR VE GÜÇ OKULU}

Güç örgütlerde yer alan aktörlerin isteklerine ulaşabilmelerinde önemli bir anahtardır. Gücü ve etkilerini analiz edebilmek, örgütte işlerin nasıl yerine getirildiğini anlamak için çok önemlidir [3]. Bu sebeple örgütler ile ilgili çalışmalarda güç ve politika kavramları daha sık incelenmektedir. Güç ve politikaları anlamak için öncelikle tanımlarına yer vermek faydalı olacaktır.

Weber gücü, bir sosyal ağdaki bir aktörün dirence rağmen kendi isteklerini gerçekleştirme pozisyonunda olma ihtimali olarak tanımlamıştır [4]. Emerson'a [5] göre güç, A'nın B'nin davranışlarını etkilemesi ve B'nin A'nın istekleri doğrultusunda davranmasını sağlayan bir kapasitedir. Pfeffer [6] gücü, olayların seyrini değiştirerek, direncin üstesinden gelmek ve insanlara başka koşullarda yapmayacaklarını yaptırmaktır. Buna göre güç, başkalarını etkileyebilme veya başkalarını kendi istediği yönde davranmaya sevk edebilme yeteneğidir. Krackhardt [7] örgütlerde güç kavramını, dirence rağmen iş yaptırabilme yeteneği ve kişisel cazibe ve çekicilik ile (karizma) insanları etkileme yeteneği olarak tanımlamıştır.

Politikalar ise Valesquez'e [8] göre, çeşitli açılardan farklı (otorite, amaç, kişilik vs.) fakat başarı açısından birbirine bağlı kiși veya grupların amaçların, yol ve yöntemlerin ve süreçlerin belirlenmesinde kullanılan karar mekanizmasına kendi görüşlerini hakim kılmak ve kendi paylarını artırmak için sahip oldukları gücü kullanarak birbirlerini etkileme sürecidir. Valesques [8] bu süreçte genel olarak kullanılan ana taktikleri, koalisyonlar ve güçlü birliktelikler kurmak, bilgi kanallarının kontrolünü ele geçirmek yoluyla değerli görülen kit kaynaklar üzerinde kontrol oluşturmak, gücün kendisinde olduğuna inandırarak diğerlerinin kendine bağımlı olduğu ilişkiler oluşturmak şeklinde siralamaktadır.

Mintzberg, Ahlstrand ve Lampel'e [9] göre örgütlerde güç ve politikalara strateji oluşumu da dahil olmak üzere her zaman rastlamak mümkündür. Benzer görüşten yola çıkarak gelişen güç okulu stratejik yönetim literatüründe 1970'li yıllardan itibaren daha sık yer almaya başlamıştır. Güç okuluna göre stratejik süreç, güç ve politikaların kullanıldığı bir etkileme sürecidir [9]. Daha geniş bir ifadeyle stratejilerin güçlü iç ve dış çıkar grupları arasındaki müzakere ve ikna süreçlerinin bir çıktısı olarak geliştiği söylenebilir. Strateji oluşumunu güç okulu açısından ele alan çalışmalar arasında Narayanan ve Fahey [10] örgüt içi koalisyonların stratejik kararları etkilemeye çalıştığını bu sebeple politik süreçlerin stratejik kararların açıklanmasında önem kazandığını öne sürmektedir. Benzer şekilde Eisenhardt ve Zbaracki [11] de stratejik seçimlerde politikalara sık rastlandığını ifade etmektedir.
Özetle denilebilir ki güç okulu örgütlerde gruplara önem atfeden söylevleri kapsar, çoğulcu bir yapıdır ve koalisyon kavramı ile ilişkilidir. Güç okuluna göre örgüt bu koalisyonlar arasında müzakere edilen aktiviteler merkezidir $[12,13]$.

\section{II.1. Gücün Kaynakları}

Stratejik süreçte gücü anlamak için gücün kaynaklarını anlamak önemlidir. Bir örgüt biçimsel ve biçimsel olmayan yapılardan meydana geldiğine göre, gücün de biçimsel ve biçimsel olmayan şeklinden bahsedilebilir. Bir kişi gücünü hem biçimsel hem de biçimsel olmayan güç kaynaklarından alabilir ve bu şekilde elde edilen güç, örgüt içinde etkisi en yüksek olan güç olarak kabul edilir [14].

Biçimsel güç örgütün, örgüt şemasında görülen pozisyonlarında bulunan kişilerin sahip olduğu güçtür ve örgüt şemasının takip ettiği hiyerarşiye göre değişir. Bu güce pozisyon gücü denir. Biçimsel güç hiyerarşinin basamaklarından yukarı çıkıldıkça artar [6]. Biçimsel gücün beş farklı kaynağı vardır [15]: yasal güç, ödül gücü, zorlayıcı güç, bilgi gücü ve temsil gücü. Mann'a [16] göre yasal gücün temelinde otorite ve bu otoritenin başkaları tarafından kabul edilmesi vardır. Ödül gücünde etkilemenin nedeni başkalarının alacakları ödüller üzerinde söz sahibi olmak ile ilișkilendirilir [14]. Zorlayıcı güç, ödül gücünün tersi olarak başkalarının cezalandırılması konusunda söz sahibi olmaktan kaynaklanan bir güç olarak kabul edilmektedir [15]. Bilgi gücünde, Schermenhorns'a [14] göre, işgal edilen pozisyonda başkalarını ilgilendiren bilgilerin toplanması söz konusu iken temsil gücüne sahip kişinin bir grup veya örgütün tamamı adına konuşma yetkisine sahip olduğu kabul edilir.

Bunun yanında örgütlerde biçimsel olmayan yapının var olması gibi biçimsel olmayan güç de vardır. Bu güç kişinin pozisyonundan değil sahip olduğu kişisel özelliklerden ve ilişkilerinden kaynaklanır [14]. Greenberg [17] kişisel gücün kaynaklarını; rasyonel ikna gücü, uzmanlık gücü, karizmatik güç ve referans gücü olarak sıralamaktadır ve rasyonel ikna gücüne sahip kişinin isteklerini diğerlerine yaptırabilmek için mantıklı konuşmalar yaptığını ve gerçekçi kanıtlar kullandığını belirtmektedir. Robbins [18] uzmanlık gücünü, bilgi veya beceri ile elde edilen etkileme gücü olarak tanımlamaktadır. Karizmatik güç ve referans gücü, yöneticinin/liderin kişiliği ile ilgilidir [15]. Karizmatik güç, sahip olduğu kaynaklar veya kişisel özelliklerden ötürü imrenilen ve kendilerine hayranlık duyulan kişilerin sahip olduğu güç [18] olarak tanımlanırken referans gücü, kişinin uzmanlığının yanında diğerlerini etkileyecek kişisel özelliklere sahip olması [17] şeklinde ifade edilmektedir. 


\section{II.2. Gücün Kapsadığı Alana Göre Sınıflandırılması}

Güç okuluna göre örgütlerde iki türlü güç alanından söz edilebilir; mikro güç ve makro güç. Mikro güç örgüt içi bireylerle ve gruplarla ilgili iken, makro güç örgüt ile çevresi arasındaki karşılıklı bağımlılığa dikkati çekmektedir [9].

\section{II.2.1. Mikro Güç}

Mikro güç, örgüt içindeki meşru ve/veya meşru olmayan güç ve politika oyunları ile ilgilenmektedir. Mikro gücün temel önermeleri şunlardır [9]:

- Örgütler çeşitli bireyler ve ilgi gruplarından oluşan koalisyonlardır. Koalisyon üyeleri arasında ilgi alanları, inançlar, gerçekleri algılamada vb. sürekli farklılıklar vardır.

- En önemli kararlar kıt kaynakların dağılımını içerir: "Kim neyi alacak." Kıt kaynaklar ve farklılıklar örgütsel dinamiklerde merkezi rolü alır ve gücü en önemli kaynak yapar.

- Hedefler ve kararlar farklı çıkar grupları arasındaki, pazarlık ve münazaralarla gelişmektedir. Buna göre örgütlerde belirlenen strateji en optimum strateji değildir daha çok en güçlü grubun isteklerini yansitmaktadir.

Örgütlerde gücü elde etmede, güç dağılımında etkili olan kaynakları belirlemek ve bunlar üzerinde stratejiler geliştirmek önemlidir. Kaynaklar; para, çalışan, araç-gereç, hammadde, bilgi ve değerli olarak algılanan diğer şeylerdir. Pfeffer'a [6] göre kaynak yaratmak, kaynaklar üzerinde denetim sağlamak ve bunu korumak, müttefik kazanmak için kritik olan pozisyonlara kendi istediği kişilerin gelmesini sağlamak, doğru insanlarla iletişim halinde olmak, bilgi elde edebilmek için doğru fiziksel konumda olmak, güçlü departmanda bulunmak güç sahibi olmada önemli unsurlardır. "Güzel ve doğru konuşmak, duyarlılık, toplumsal ilişskilerde ustalık, beceriklilik, herkes tarafından sevilmek, dışadönüklük, özgüven, ataklık, hırslı olmak" [19] gibi vasıflar da gücü elde etmek için gerekli kişisel özellikler olarak sayılabilir.

\section{II.2.2. Makro Güç}

Makro güç, örgütü diğer örgütlerle kontrol ve işbirliği içinde stratejik manevralar, çeşitli işbirlikleri ve networklerle oluşturduğu kollektif stratejilerle kendi çıkarını yükseltmeye çalışan sosyal aktör olarak ele almaktadır [9].

Makro güç, çıkar grupları analizi, stratejik manevralar ve işbirliği stratejisi oluşturma şeklindeki hareketleri inceler. Bir yaklaşıma göre örgüt çıkar gruplarını analiz ederek, savunmacı, saldırgan, bekleme ya da kuralları değiştirme stratejilerinden birini tercih eder [20]. Mintzberg, Ahlstrand ve Lampel'e [9] göre her bir gruba ilişkin doğru ve tam bilgiyi elde etmenin çaba ve zaman gerektirmesi nedeniyle çıkar grupları analizi zor bir süreçtir. Aynı eserde stratejik manevralar ile işbirliği içinde kollektif stratejilere de değinilmiştir. Buna göre stratejik manevralar; "rakiplerle iletişim kurmak, kavga etmek yerine ortak bir çıkar belirleyerek ya da yaratarak birlikte hareket etmek" şeklinde tanımlanmaktadır. Buna ek olarak eserde işbirlikleri ve networklerin hızlı artması ile strateji oluşumunun örgütün tek başına değil, rakiplerle birlikte yürüttügü bir faaliyet haline geldiği, firmanın bir network ilişkileri boyunca müzakereler yaparak, kollektif bir strateji oluşturduğu ifade edilmektedir.

\section{II.3. Güç Okulu: Tarihsel Süreç İçindeki Gelişimi}

1970'lere kadar strateji oluşumunun bir rasyonel karar verme süreci olduğu vurgusu hakimdi. $\mathrm{Bu}$ döneme kadar örgütler, tercihleri bilinen ve uyum içinde olan, sebep-sonuç ilişkisi içinde iyi anlaşılmış ve bilgi akışı çoğu konuda yeterli olan yapılar olarak görülmekteydi [13]. Eisenhardt ve Zbaracki [11] stratejik karar vermede güç okulu yaklaşımının temellerinin 1950'lerin politik bilimler literatürüne dayanmakta olduğunu kabul etmektedir. 1970 ve 1980 'li yıllarda Pfeffer ve Salancik [21] ve Mintzberg [22] örgütleri, içte ve dışta farklı ilgi ve istek koalisyonlarından oluşan bir politik varlık olarak tanımlamaya başlamıştır. Bu görüşe göre kararlar, farklı amaçlardaki karar vericilerin biraraya gelerek koalisyonlar kurmaları sürecinin bir sonucudur ve en güçlünün isteklerini yansıtır [11]. Bu perspektiften güç okulu örgütlerde gruplara önem atfeden kuramları temel alır [13]. Bunlar arasında burada Stratejik Koşul Bağımlılığı Kuramı, Kaynak Bağımlılığı Kuramı ve Kaynak Bazlı Firma Kuramı incelenecektir.

\section{II.3.1. Stratejik Koşul Bağımlılığı Kuramı}

Stratejik koşul bağımlılığı kuramı, örgütsel problemlerin ve belirsizliklerin üstesinden gelebilen altbirimlerin (bireyler, departmanlar) gücü kendisinde topladığını ileri sürmektedir. Örneğin örgüt varlığını tehdit eden yasal sorunlarla karşılaştığında, hukuk departmanı güç kazanacak ve örgütsel kararları etkileyecektir [23]. Hickson ve diğerleri [24] stratejik koşul bağımlılı̆̆ına göre gücü elde etmeyi doğrudan etkileyen faktörleri; belirsizlikle baş edebilme, ikame edilemez olma ve merkezi rolde olma şeklinde siralamaktadır.

Güç okuluna göre stratejik koşul bağımlılığının sağladığı anlayışla örgüt içinde belirsizlikle baş edebilen birim ya da kişiler gücü kendisinde toplayarak örgüt için en kritik kararları alabilecek ve faaliyetleri belirleyebilecek, örgütün stratejisini kendi istekleri doğrultusunda etkileyebilecektir. Belirsizlikle başedebilen 
birim ya da kişilerin etkisiyle gelişen stratejilerin örgüt için kritik bir rekabet avantajı oluşturabilmesi muhtemeldir ancak diğer taraftan bu şekilde ortaya çıkan stratejiler en güçlünün gücünü sürdürebilmek amacını da yansitabileceği için her zaman örgüt için en optimum stratejiler olmayabilir.

\section{II.3.2. Kaynak Bağımlılığı Kuramı}

$\mathrm{Bu}$ kurama göre her örgüt fonksiyonlarını gerçekleştirmede ihtiyaç duyduğu kaynaklar için çevresine bağımlıdır [25]. Örgütlerde sadece çeşitli seviyedeki yöneticiler değil çok sayıda farklı aktör vardır. Buna ek olarak örgütler, sendikalar, devlet, tüketiciler, tedarikçiler ve yatırımcılarla da ilişki içindedir. Samuel'e [26] göre tüm bu oyuncular arasında bir ilişki ağı oluşmuştur ve aralarında karşılıklı bağımlılık vardır. Kaynağın kritik öneme sahip olması ve mevcut olup olmaması güç mücadelelerine yol açıcı bir etken olarak görülür [27]. Kurama göre örgüt için kritik kaynak sağlayan ve ilişki ağının merkezinde olan aktörler gücü kendilerinde toplayacaklardır.

Kaynak bağımlılığı kuramından hareketle güç okuluna göre örgütün stratejisinin oluşumunda kritik kaynağa sahip odakların etkili olacağını söylemek mümkündür. Buna bağlı olarak örgütte kritik kaynaklara sahip olamayanlar kendi güç alanlarını genişletmek için çeşitli koalisyonlar kurarak politik oyunlar ile niyetlenilen stratejiyi etkilemeye çalışacaklardır. Böylelikle örgüt içinde sürüp giden bir çatışma ortamı doğacak ve güç sahibi olmak en önemli kaynak haline gelecektir [9]. Bu durumun kimi örgütlerde en küçük kararlarda bile politik çekişmelerin doğmasına yol açabileceği, dolayısıyla örgüt için zaman ve kaynak israfına sebep olabileceği hatta örgütün stratejisini belirlemesine engel olabileği söylenebilir.

\section{II.3.3. Kaynak Bazlı Firma Kuramı}

Kaynak Bazlı Firma Kuramı stratejik yönetimde gelişmekte olan önemli kuramlardan biridir. Barney "Firma Kaynakları ve Sürdürülebilir Rekabet Avantajı" (1991) isimli makalesinde kaynak bazlı firma kuramına göre rekabet avantajının sürdürülebilmesinin firmanın değerli, kıt, taklit edilemeyen ve stratejik olarak eşit düzeyde ikamesi bulunmayan kaynakları oluşturmasına dayalı olduğunu söylemektedir [28]. Buna ek olarak Baden-Fuller güçlü kaynaklara sahip firmaların her zaman kazanmadığını, firmaların bu kaynaklardan yararlanmak için doğru yeteneğe sahip olması gerektiğini belirtmektedir [28]. Burada doğru yetenek ile örgütsel bağlama işaret edildiği söylebilir. Oliver [29], örgüt seviyesinde, rasyonel kaynakların seçilmesinin örgüt çalışanlarının politik ve kültürel olarak bu kaynakları kullanmak istemelerine bağlı olduğunu söylemektedir. Aynı eserde Oliver, firmaya rekabet avantajı sağlayacak kaynakların örgütün kültürel, politik ve öğrenme yapısına uymadığı için çalışanlar tarafından reddedildiği durumlar olabildiğini belirtmiştir. Benzer şekilde yöneticiler de sahip oldukları güce tehdit olarak algılamaları durumunda kaynak değişimine sıcak bakmayabilmektedirler.

Özetle denilebilir ki kaynak bazlı firma teorisi örgüte rekabet avantajı sağlayacak kaynakların stratejik olarak benimsenmesinde örgütsel bağlamı oluşturan örgüt kültürü ve politikaların etkisine işaret etmektedir. Buradan hareketle kaynak bazlı firma kuramını, örgütteki politik yapıya vurgu yapması sebebiyle güç okulu çerçevesinde değerlendirmenin mümkün olduğu söylenebilir.

\section{II.3.4. Güç ile İlgili Yaklaşımlar}

Güç okulunun temel aldığı yukarıda yer verilen kuramlara bakıldığında, genellikle örgüt içinde kritik veya kıt kaynaklara sahip olan birey veya bölümlerin güç sahibi olduğu görülmektedir. Gücün elde edilmesinde kaynakların önemine vurgu yapan bu kuramlara temel teşkil eden iki zıt görüş mevcuttur.

Mills'in [30] öne sürdüğü ilk görüşe göre güç, kaynakların kontrolü ile ilgili olduğundan bir tarafın kazanmasının diğer tarafın kaybetmesi anlamına geldiği sıfır toplamlı bir oyundur. Mills, toplumu tabakalı ve çatışmalı girişimler olarak görmektedir. Dolayısıyla kaynakların genellenebilir olduğunu reddeder ve sıfır toplamlı oyun görüşüne ulaşır. $\mathrm{Bu}$ görüşe zit olarak Parsons [31] gücün, kaynakların hareketliliğinden kaynağını aldığını bu sebeple sifir toplamlı bir oyun olmadığını ileri sürmektedir. Parsons, toplumu ve örgütleri fonksiyonel ve uzlaşmaya dayalı sistemler olarak görmektedir. Bunun sonucu olarak kaynakları potansiyel çatışma unsuru olarak değil aksine genişleme kapasitesinin aracı olarak kabul etmektedir.

\section{II.4. Güç Okuluna Yöneltilen Eleştiriler}

Güç okuluna yönetilen en önemli eleştirilerden biri, sürekli olarak bölünme ve parçalanmalara odaklanarak, çatışma içeren durumların yapıcı yönlerini gözden kaçırabilme olasılığı taşımasıdır [9]. Mintzberg ve diğerleri [9] tarafindan okula yöneltilen ikinci eleştiri ise strateji oluşumunda tek faktörün güç olmadığı bu sebeple gücün strateji oluşturmadaki rolünün fazla abartıldığı şeklindedir.

Diğer taraftan güç okuluna yapılan olumlu eleştirilere göre; güç işlerin yerine getirilmesini ve hedeflere ulaşılmasını sağladığı gibi politikalar da, çevredeki değişimlere duyarlı olmada, yaratıcılığın artmasında, değişime dirençle başetmede ve değişimin gerçekleştirilmesini kolaylaştırmada [32,33] etkili araçlardan biri olarak kabul edilir. 
Buraya kadarki bölümde güç ve politikalar kavramsal olarak açıklanarak güç okulunun gelişimi ve strateji sürecine bakışına yer verilmiştir. Yukarıdaki açıklamalar 1şı̆̆ında güç okulunun önermeleri şu şekilde özetlenebilir: Güç ve politikalar hem örgüt içinde hem de örgüt dışında strateji oluşumunu şekillendirmektedir. Örgüt içi farklı ilgi grupları çeşitli koalisyonlar yoluyla amaç ve isteklerini kabul ettirmek için ikna ve pazarlık yollarını kullanmaktadırlar. Örgütler arasında güç mücadeleleri çeşitli işbirlikleri, ağlar ve stratejik manevralar yoluyla gerçekleşmektedir. Güç okulunun bu önermeleri doğrultusunda bu okula göre stratejinin hem örgüt içi hem örgütlerarası müzakere süreçleri sonucunda oluştuğu söylenebilir.

\section{III. ÖRGÜTSEL BAĞLAMDA STRATEJIK PARADOKSLAR VE PERSPEKTIFLER}

$\mathrm{Bu}$ bölüm stratejinin belirlenmesinde ve uygulanmasında örgütün iç çevresine odaklanmakta ve stratejistin isteklerini örgütte ne ölçüde yaptırabileceğinin cevabını aramaktadır. Stratejist örgütü istediği gibi şekillendirebilir mi, yoksa örgütün kendi dinamikleri vardır ve stratejisti bunlar mı şekillendirmektedir? Daha kısa bir ifadeyle, strateji mi örgütü izler, örgüt mü stratejiyi izler?

Bu sorunun cevabı örgütsel bağlamı aşağıda geniş olarak ele alınacak iki farklı paradoks ve perspektif çerçevesinden değerlendirmek suretiyle verilebilir. De Wit ve Meyer'e [2] göre bunlardan ilki, liderin strateji üzerinde karar vermesi ve örgütün bütün olarak bu stratejiyi uygulamaya yönlendirilmesini ifade eden kontrol paradoksu ve bununla ilişkili örgütsel liderlik perspektifidir. İkincisi ise stratejinin stratejist tarafından seçilmesi değil, örgütün karmaşık dinamik yapısı içinden gelişmesini ifade eden kaos paradoksu ve bununla ilişkili örgütsel dinamikler perspektifidir.

\section{III.1. Örgütsel Bağlamda Stratejik Paradokslar}

Lewis, paradoksu "çatışan gerilimler arasında ne bir uzlaşma ne de bütünüyle bir ayrışmadır fakat daha çok ikisinin de farkında olmaktır" şeklinde tanımlamaktadır [34]. Bu tanımdan hareketle örgütsel bağlamda stratejiyi oluşturma ve uygulamada iki uç nokta olarak kontrol ve kaos paradoksu incelenebilir. İnsanların çevrelerini kararlarına uydurma gücünün olduğu duruma kontrol, çevrelerinin kimsenin kontrol edemediği dinamikler tarafından şekillendiği duruma da kaos denilebilir.

\section{III.1.1.Kontrol Paradoksu}

Kontrol, bireylerin örgütsel hedefleri gerçekleştirecek davranışları gösterme ihtimalini yükseltme girişimleri olarak tanımlanmaktadır [35]. Örgütsel bağlamda kontrol paradoksuna göre, örgüt lideri stratejiyi belirlemede tümüyle kontrol sahibi olduğunda, örgüt stratejiyi uygulamak için yönlendirilebilir. Böyle bir durumda örgüt, liderin kontrol panelinde oturduğu mekanik bir sisteme benzemektedir. Lider teknik yeterlilikler ölçüsünde makine üzerinde her türlü emir yetkisine sahiptir [2]. Stratejiyi belirlemek için lider iç ve dış çevreyi sürekli izler, analiz yapar, alternatif stratejileri tarar ve aralarından uygun olanı seçer. Ardından bu strateji doğrultusunda hedefleri belirler ve kaynakları paylaştırır. Tüm bunları başarabilmek için lider çok iyi iletişim ve yönetim becerilerine sahip olmalıdır [36],[37]. $\mathrm{Bu}$ anlamda kontrol paradoksu strateji oluşturma ve uygulamayı doğrudan üst yönetimin bir fonksiyonu olarak görmektedir.

Kontrol paradoksunun mantıksal düşünce paradoksu ya da rasyonel düşünce perspektifi [36] olarak da ele alınan Newton fiziği paradigması ile paralellik gösterdiği söylenebilir. Schwartz ve Ogilvy’nin "Gelişen Paradigma: Düşünce ve İnancın Değişen Kalıpları" (1979) isimli araştırmasına göre, nesnellik, nedensellik, mekanik evren ilkeleri bu paradigmanın temel varsayımlarındandır. Nesnellik ilkesine göre bilme akıl yoluyla anlama ile mümkündür ve bu süreçte gözlenen ile gözlemci kesin sınırlarla birbirinden ayrılmıştır. Nedensellikte ise parçalar arasında nedensellik ilişkileri açıklanabilirse sonuçları da açıklanabilir. Mekanik evren ilkesine göre makine örneği evrenin işleyişine uyarlanmaktadır. Gerçekliğin temel yapı taşları olan en küçük parçacıklar ve bunların davranışını yöneten bir seri yasa olduğunu, bu yasaları keşfetmenin dünyanın geleceğine ilişkin tahminlerde bulunmaya yardımcı olduğunu varsaymaktadır [38].

Kontrol paradoksu da benzer şekilde liderin, bir makinenin yöneticisi rolüyle iç ve dış çevreyi analiz ederek nedensellik ilişkilerini belirlemesi ve tespit ettiği bu nedensellik ilişkisine dayanarak geleceğe yönelik sonuçları bugünden tahmin edebileceği varsayımından hareketle stratejiyi oluşturduğunu öne sürmektedir. Bu anlamda kontrol paradoksunun stratejik düşünmeyi doğrudan üst yönetimin yürüttüğü mantıksal bir aktivite olarak gördüğü söylenebilir.

Güç ile ilgili yaklaşımlar açısından baktığımızda Mills'in [30], gücün kaynakların kontrol edilmesi olduğundan sıfır toplamlı bir oyun olduğunu kabul eden görüşünün kontrol paradoksu ile ilişkili olduğu söylenebilir.

\section{III.1.2.Kaos Paradoksu}

Stacey [39] bilimsel anlamda kaos kavramının çoğunlukla doğada ve insan topluluklarında görülen, doğrusal olmayan sistemlerden doğan düzensiz davranış kalıpları olarak tanımlandığını belirtmektedir. Gleick'e [40] göre, günlük yaşantıda gözlemlediğimiz ve birbirleri ile sanki ilişkisi yokmuş gibi görünen, düzensiz, tesadüf eseriymiş gibi izlenim veren durum ve olayların, aslında 
muazzam bir düzenin parçası olması kaosu ifade etmektedir. Kaotik sistemler önceden tahmin edilemeyen ve durağan olmayan davranışlar gösteren karmaşık, doğrusal olmayan dinamik sistemlerdir [41]. Bu sebeple Stacey [39] kaotik sistemlerde neden sonuç ilişkisi ve uzun dönemli gelecek tahminleri yapmanın mümkün olmadığını söylemektedir.

Kaos kuramı, en basit sistemlerin bile olağanüstü sorunlar yarattığını, ancak sistem içinde düzenin kendi kendine oluştuğunu ileri sürmektedir [41]. De Wit ve Meyer'e [2] göre, örgütler de olayların çok sayıda karmaşık faktörün karmaşık etkileşimlerine bağlı olarak geliştiği kaos durumu barındıran karmaşık sistemlerdir. Buradan hareketle örgütsel bağlamda strateji oluşumunu kaos paradoksu olarak açıklayan yaklaşımlar [39],[41] ortaya çıkmıştır. Örgütsel bağlamda kaos paradoksuna göre strateji, stratejist tarafindan seçilmemekte fakat örgüt içindeki karmaşık dinamik sistemlerden doğmaktadır [2]. Diğer bir ifadeyle strateji örgütsel bağlamın bir sonucu olarak ortaya çıkmaktadır ve liderin stratejiye çok az bir etkisi olabilir.

Kaos paradoksu, Einstein fiziği paradigması [38] ya da yaratıcı düşünce perspektifi [2] olarak da ele alınan bilimde yeni yükselen bir paradigma ile paralellik göstermektedir. Schwartz ve Ogilvy, Einstein'in "Görelilik Kuramı" ve ardından Heisenberg'in "Belirsizlik İlkesi" ile gelişen bu yeni paradigmanın Newton paradigmasının varsayımlarını oldukça sarstığını ileri sürmektedir. Schwartz ve Ogilvy'ye göre bu yeni paradigma şu özellikleri göstermektedir [38]:

- Gerçeklik karmaşıktır, her sistem için doğru genel geçer yasalar yoktur fakat her sistem kendine özgü birtakım özellikler geliştirir. Dolayısıyla olay ve olgular kendi ortamları içinde incelenmelidir.

- İlişkiler doğrusal nedensellik içinde değil, karşılıklı nedensellik içindedir. A ve B karşılıklı etkileşerek birlikte evrimleşir ve değişirler. $\mathrm{Bu}$ da $\mathrm{A}$ ve $\mathrm{B}$ ilişkisinin sonucunu başlangıçta görmeyi zorlaştırır ve belirsizlik oluşturur. Gelecek ve yön belirsizdir. Olasılıklar belirlenebilir ancak kesin sonuçlar kestirilemez.

- Nesnellik diye birşey yoktur. Herkesin kendine özgü bir kavramsal haritası [42] vardır ve bu olaylara ve olgulara bakış açısını etkiler. Yani öznellik kaçınılmazdır.

Görüldüğü gibi kaos paradoksu da Einstein fiziği paradigması ile ortak olarak karmaşıklığı, karşılıklı etkileşimi ve öznelliği vurgulamaktadır. Geleceği bilmek, uzun dönemli planlar yapmak ve kontrol sağlamak çok zor görünmektedir.
Sonuç olarak kaos paradoksuna göre kaotik bir sistem olan örgütte strateji oluşumunu, analiz, öngörü ve kontrol üzerinde yoğunlaşan [43] kontrol paradoksu ile değil, bunun yerine örgütün kendi iç dinamiğinden ortaya çıkan bir süreç olarak açıklamak mümkündür. Güç ile ilgili yaklaşımlar açısından baktığımızda Parsons'un [31], gücün kaynakların hareketliliğinden kaynağını aldığından sıfır toplamlı bir oyun olmadığı yönündeki görüşünün, kaos paradoksu ile ilişkili olduğu öne sürülebilir.

\section{III.2. Örgütsel Bağlamda Perspektifler}

Stratejinin oluşumu ve uygulanması konusunda yapılan çalışmalarda süreç farklı şekillerde kategorize edilmiştir. Örneğin Bourgeois ve Broadwin "Stratejinizi Harekete Geçirme" [44] isimli makalesinde stratejiyi uygulamada şu beş yaklaşımdan söz etmektedir: strateji sürecinin lider ya da üst yönetim tarafindan gerçekleştirildiğini iddia eden emir verici yaklaşım, örgütsel değişim yaklaşımı, stratejiyi örgütün bir ürünü olarak gören işbirliği yaklaşımı, kültürel yaklaşım ve gelişim yaklaşımıdır. Johnson [36] ise strateji oluşumu ve uygulamasını rasyonel görüş ve örgütsel hareket görüşü olarak ikiye ayırmıştır. Her iki eser de temelde stratejinin ya liderin ya da örgütün bir ürünü olduğunu söylemektedir. Benzer şekilde De Wit ve Meyer [2] de, strateji oluşumunu ve uygulanmasını kontrol ve kaos paradoksu ekseninde değerlendirerek iki ana perspektif ortaya koymaktadırlar. Bunlar; örgütsel liderlik perspektifi ve örgütsel dinamikler perspektifidir.

De Wit ve Meyer'e [2] göre örgütsel liderlik perspektifi, kontrol paradoksuna dayanmaktadır. Çoğu stratejistin, liderin örgüt üzerinde kontrolü olduğunu ve örgüt dinamikleri tarafından sinırlandırılmaya ihtiyacı olmadığını varsaydığını söylemektedirler. Buna göre örgüt lideri stratejiyi belirlemede tümüyle kontrol sahibi ise, örgüt stratejiyi uygulamak için yönlendirilebilir. Yine De Wit ve Meyer'e [2] göre örgütsel dinamikler perspektifi ise, kaos paradoksuna dayanmaktadır. $\mathrm{Bu}$ yaklaşıma göre strateji, stratejist tarafından seçilmemekte fakat kaotik bir sistem olan örgüt içindeki karmaşık dinamik sistemlerden doğmaktadır. Ayrıca yine bu görüşe göre liderler örgüt bağlamının bir ürünüdür ve örgütün stratejisinde sadece marjinal bir etkileri olabilir.

Bu kısımda örgütsel liderlik perspektifi ile örgütsel dinamikler perspektifi kontrol ve kaos paradoksu üzerinden karşılaştırılacak, böylelikle örgütsel bağlam anlaşılmaya çalışılacaktır. Kontrol ve kaos paradoksu üzerinden yapılacak bu karşılaştırma her iki perspektifi, yukarıda yer verilen Newton fiziği paradigmasından yeni bilimsel anlayışın temelini oluşturan Einstein fiziği paradigmasına geçiş çerçevesinde değerlendirmeyi mümkün kılacaktır.

\section{III.2.1.Örgütsel Liderlik Perspektifi}


Örgütsel liderlik perspektifine göre strateji oluşturma sürecini lider yürütür. $\mathrm{Bu}$ perspektif kontrol paradoksuna dayanmaktadır. Kontrol paradoksu mantıksal düşünceyi temel almakta ve buna bağlı olarak liderin kendi aklını kullanarak iç ve dış çevreyi doğru analiz edebileceğini, nedensellik ilişkilerini belirleyebileceğini ve bugünden geleceğe yönelik sonuçları tahmin edebileceğini savunmaktadır. Kontrol paradoksuna dayanan örgütsel liderlik perspektifine göre stratejik karar verme süreci, doğrudan liderin/üst yönetimin yürüttüğü mantıksal bir süreçtir ve sistematik çevre analizi, içteki güçlü ve zayıf yönleri belirleme, belirli hedefler koyma, hedefleri gerçekleştirmek için geniş bir plan hazırlama adımlarını içermektedir [45]. Lider, topladığı bilgiler doğrultusunda örgüt için en iyi vizyonu belirler ve örgüt üyelerinden bunu uygulamalarını ister, kimi durumlarda da uygulama için gerekli yapısal değişiklikleri ve teşvikleri de düzenler [44].

Örgütsel liderlik perspektifi Chandler'ın “Strateji ve Yapı" [46] adlı eserinde "örgüt stratejiyi izlemeli" şeklindeki ifadesine uymaktadır. Eserde Chandler'ın 50 büyük Amerikan endüstri şirketi üzerinde yaptığı araştırmada elde ettiği bulgulara göre, operasyonel faaliyetleri üst yönetim planlamakta, koordine etmekte, gerekli kaynakları onlara tahsis etmekte ve sonuçları değerlendirmektedir. Chandler'a göre, üst yönetim bir arabanın direksiyonunda olduğu gibi kontrolü eline almalı strateji sürecini yürütmeli, isteklerini örgüte kabul ettirebilmelidir. Örgütün yapıs1, karar vericinin niyetlendiği stratejiye adapte edilmelidir.

Örgütsel liderlik perspektifi savunucularından Christensen ve diğerlerine [37] göre, örgütsel bağlam zaman zaman liderin strateji oluşturmasını ve uygulamasını sınırlayabilir. Örneğin astların stratejik sürece dahil edilmemesi, stratejiyi benimsemelerini ve motive olmalarını olumsuz etkileyerek liderin stratejiyi uygulama özgürlüğünü kısıtlayabilir. Ancak bu görüşe göre, bu durum da örgütsel liderlik perspektifinin zayıflığı ile değil, liderin yönetimdeki başarısızlığı olarak görülmelidir [37].

Özet olarak örgütsel liderlik perspektifi, örgütsel dinamiklerin değil liderin önemli olduğunu savunmakta, başarılı liderin her zaman örgütün kontrolünü elinde bulundurabilen ve örgütü amacına ulaştıran çok önemli kişiler olduğunu öne sürmektedir.

\section{III.2.2.Örgütsel Dinamikler Perspektifi}

Örgütsel dinamikler perspektifine göre strateji örgütsel dinamiklerin bir sonucu olarak ortaya çıkmaktadır. $\mathrm{Bu}$ perspektif kaos paradoksunu temel almaktadır. Yukarıda açıklandığı üzere kaos paradoksu örgütü kaotik bir yapıyı barındıran, karmaşık ve dinamik bir sistem olarak görmektedir. Kaos kuramına göre kaotik sistemlerin düzensiz, belirli bir kalıba oturtulamayan yapısı sebebiyle uzun vadeli geleceğe yönelik tahminler yapmak mümkün değildir. $\mathrm{Bu}$ sebeple kaos paradoksu, stratejik sürecin stratejist tarafindan belirlenen mantıksal bir süreç olarak değil fakat örgütün karmaşık dinamik yapısı içinden gelişen süreç olduğunu öne sürmektedir $[2]$.

Kaos paradoksuna dayanan örgütsel dinamikler perspektifinin savunucularına göre örgütün politik, kültürel yapısı ve öğrenme dinamikleri kaotik iç dinamiklerini oluşturmakta ve bunlar üst yönetimin örgütü istediği yönde yönetme gücünü kısıtlamaktadır [2]. $\mathrm{Bu}$ perspektife göre; bazı liderler kontrolün ellerinde olduğunu ve örgütün gelecek yönünü seçtiklerini zannederler, oysa örgüt üyeleri strateji oluşturma sürecinde önemli rol oynamaktadırlar [47]. Johnson'un [36] ifade ettiği biçimiyle, örgüt üyelerinin sahip olduğu farklı politik amaçlar, kültürel yapı ve öğrenilmiş yetkinliklerle yapılan yatırımların değişmesinin zor olması gibi faktörler strateji oluşturma ve uygulama sürecini etkilemektedir. Johnson liderlerin bilişsel yapılarının da strateji oluşturmayı etkilediğini belirterek, strateji oluşumunda mantıksal düşüncenin nesnellik ilkesinin değil, Einstein fiziği mantığının öne sürdüğü öznellik/görecelilik ilkesinin esas olduğunu ifade etmiş olmaktadır. Aynı eserde Johnson liderlerin rasyonel olduklarını sansalar da gerçekte örgüt kültürünün şekillendirdiği bilişsel haritalarının, çevreyi algılama biçimlerini gösterdiğini ileri sürmektedir. $\mathrm{Bu}$ bilişsel haritalar örgüt kültürü, örgütteki efsaneler ve ritüeller yoluyla meşruluk kazanmıştır. Dolayısıyla liderin kararlarının gözlemlediği çevreden bağımsız olmadığı söylenebilir. Bu sebeplerle örgütsel dinamikler perspektifi liderin örgütsel bağlamı değil, örgütsel bağlamın lideri ve stratejiyi şekillendirdiğini iddia etmektedir.

Stacey [39] "Kaostan Gelișen Düzen Olarak Strateji" isimli makalesinde, üst yönetimin örgütü ve stratejisini kontrol edemeyeceği ve etmeye çalışmaması gerektiğini söylemektedir. Buna göre, strateji oluşumunda yer alan örgütsel dinamikler öğrenme ve değişim yöneticiler tarafindan kontrol edilemeyecek kadar karmaşıktır. Ona göre kontrolün olmaması örgütün başıboş sürükleneceği anlamına gelmez. Örgütsel dinamikler, kaotik sistemlerde olduğu gibi, kontrollü davranış üretebilen kendi kendine organize olma yeteneğine sahiptir. Gerçek stratejik değişim bir kaosun yaşanmasını gerektirir. Böylece süregelen düzen bozularak yeni çözümler aranacaktır. Yöneticinin görevi böyle bir değişim ortamını yaratacak şekilde örgütsel bağlamı etkilemektir. Bu sayede beklenmedik stratejiler kendiliğinden oluşacaktır.

Tablo.1'de örgütsel liderlik ile örgütsel dinamikler perspektifleri karşılaştırılmıştır. Buna göre tabloda örgütsel liderlik perspektifinin kontrol, örgütsel dinamikler perspektifinin ise kaos paradoksuna uygun 
olarak stratejik değişim ve uygulamada gösterdikleri özellikler görülmektedir.

Tablo.1. Örgütsel Liderlik ve Örgütsel Dinamikler Perspektiflerinin Karşılaştırılması

\begin{tabular}{|c|c|c|}
\hline & $\begin{array}{l}\text { Örgütsel } \\
\text { Liderlik } \\
\text { Perspektifi } \\
\end{array}$ & $\begin{array}{l}\text { Örgütsel } \\
\text { Dinamikler } \\
\text { Perspektifi }\end{array}$ \\
\hline Vurgu & Kontrol & Kaos \\
\hline $\begin{array}{l}\text { Örgütsel } \\
\text { değişimler }\end{array}$ & $\begin{array}{l}\text { Kontrol } \\
\text { edilebilen } \\
\text { oluşturma süreci }\end{array}$ & $\begin{array}{l}\text { Kontrol edilemeyen } \\
\text { evrim süreci }\end{array}$ \\
\hline $\begin{array}{l}\text { Değişim } \\
\text { süreci }\end{array}$ & $\begin{array}{l}\text { Lider davranışı } \\
\text { emreder }\end{array}$ & $\begin{array}{l}\text { Davranış geçmişten } \\
\text { gelişir }\end{array}$ \\
\hline $\begin{array}{l}\text { Değişiminin } \\
\text { belirleyicisi }\end{array}$ & $\begin{array}{l}\text { Liderin vizyonu } \\
\text { ve becerileri }\end{array}$ & $\begin{array}{l}\text { Politik, kültürel ve } \\
\text { öğrenme } \\
\text { dinamikleri }\end{array}$ \\
\hline $\begin{array}{l}\text { Değişimin } \\
\text { türü }\end{array}$ & $\begin{array}{l}\text { Üstten alta, } \\
\text { mekanik }\end{array}$ & Etkileşimli oluşum \\
\hline $\begin{array}{l}\text { Örgütsel } \\
\text { yumuşaklık }\end{array}$ & Çok, hızlı & Az, yavaş \\
\hline $\begin{array}{l}\text { Adaptasyon } \\
\text { yönü }\end{array}$ & $\begin{array}{l}\text { Örgüt stratejiyi } \\
\text { izler }\end{array}$ & Strateji örgütü izler \\
\hline $\begin{array}{l}\text { Normatif } \\
\text { uygulama }\end{array}$ & $\begin{array}{l}\text { Stratejiyi oluştur } \\
\text { sonra uygula }\end{array}$ & $\begin{array}{l}\text { Strateji oluşturma } \\
\text { ve organize etme iç } \\
\text { içe }\end{array}$ \\
\hline Bakış açısı & İradi & Deterministik \\
\hline
\end{tabular}

Kaynak:De Wit, B. \& Meyer, R. (1998). Strategy, Process, Content, Context: An International Perspective. London: International Thomson Business Press, 657 [2].

Tablo.1'den de görüldüğü gibi özet olarak örgütsel liderlik perspektifi kontrol paradoksunu temel almaktadır. Buna göre lider mantıksal düşünür, geçmiş kültürel, bilişsel altyapısından ve öğrenmelerinden etkilenmeden, nesnel bir bakış açısıyla, içinde bulunduğu çevrenin neden-sonuç ilişsisini analiz etmektedir. $\mathrm{Bu}$ analizleri sonucunda geleceğe yönelik tahminler yaparak örgüt için bir strateji belirlemekte ardından da bu stratejinin uygulanması için gerekli örgütsel değişimleri devreye sokmaktadır. Örgüt liderin kontrolü altındadır. Lider, bir lokomotifin kaptanı gibi gidilecek yönü belirler ve götürür.

Örgütsel dinamikler perspektifi ise stratejik süreci, örgütsel liderlik perspektifinden oldukça farklı şekilde açıklamaktadır. Örgütsel dinamikler perspektifi, Einstein fiziği paradigmasından etkilenen ve örgütleri karmaşık ve kaotik sistemler olarak gören kaos paradoksuna dayalıdır. Örgüt kültürü, politikalar ve öğrenilmiş yetkinlikler, yapılan yatırımları değiştirmenin zorluğu ve liderin bilişsel yapısı gibi örgütsel dinamikler lideri sınırlamaktadır. $\mathrm{Bu}$ sebeple örgütsel dinamikler perspektifine göre stratejik süreç örgütsel bağlamın bir sonucu olarak ortaya çıkmaktadır.

\section{GÜÇ OKULU AÇISINDAN ÖRGÜTSEL BAĞLAM}

Bu bölüme kadar strateji oluşturma ve uygulamada örgütsel bağlamın yerini, örgütsel liderlik ve örgütsel dinamikler perspektifinden ele alan iki yaklaşıma değinilmiş̧tir. Bu bölümde güç okulu açısından örgütsel bağlam değerlendirilmeye çalışılacaktır.

De Wit ve Meyer [2] yeni bir stratejik yön geliştirmenin politik etkileşim ve karmaşık öğrenme süreçlerini gerektirerek tartışma ve çatı̧̧ma kaosu doğurduğunu ifade etmektedir. Diğer bir anlamıyla yeni bir strateji geliştirmek ve bunu uygulamak bir takım süreçleri ve zorlukları barındırır. Örgütü yalnızca liderin ya da yönetim takımının kontrolünde işleyen bir makine gibi ele alan örgütsel liderlik perspektifi ile, örgütü farklı grupların politik, kültürel yapısı ve öğrenme deneyimlerinin bir sonucu olarak ele alan örgütsel dinamikler perspektifi iki zıt noktada konumlanmış görünmektedir. Buna göre güçlü bir kültür, merkezi güç, formal prosedürler, katı yapıların görüldüğü merkezi örgütler kontrol durumunu yansitırken, örgütün çok sayıda alt birime ayrılması, bölünmüş kültür ve gücün merkezi olmaması kaos durumunu gösterir. Oysa gerçekte örgütleri kontrol ve kaos arasında bu kadar kesin çizgilere oturtmak zordur. Örgütlerin birçoğunda stratejik süreçte örgütsel liderlik perspektifi ile örgütsel dinamikler perspektifinin iç içe yürüdüğünü söylemek mümkündür.

Yeni bilimsel paradigmanın [38] getirdiği karşılıklı nedensellik, öznellik, karmaşıklık, belirsizlik kabulleri ile örgütsel dinamikler perspektifinin örtüştüğü, örgütsel liderlik perspektifinde ise liderin kontrol merkezli rolünün yeniden tanımlanması gerekliliği görülmektedir. Örgütsel liderlik perspektifinin stratejik süreçte örgütü mekanik bir sistem olarak gördüğü, liderin mutlak nedensellik ve nesnellik içinde örgütün iç ve dış çevresini analiz ederek, geleceğin önceden kestirilebilir olduğu kabulüyle en uygun stratejiyi geliştirdiği anlayışı yeni bilimsel paradigmayla değişime uğramaktadır.

Örgütsel bağlam ve güç okulu ilişkisini, Mills'in [30] kontrol paradoksuna ve Parsons'un [31] kaos paradoksuna yakın duran görüşleri çerçevesinden değerlendirmek faydalı olacaktır. Mills'e [30] göre güç, kaynakların kontrolü sonucu elde edilen sifir toplamlı bir oyundur. $\mathrm{Bu}$ görüşe göre örgütteki her bir aktör sınırlı kaynakların en çoğunu ve en iyisini almak için çaba gösterecektir denilebilir. Böylesine bir yarışta, bir grup ne kadar fazla pay alırsa diğeri o ölçüde fazla kaybedecektir. Oyun teorisinde bu duruma "sifir toplam oyunu" denir ki toplam kazanç ve toplam faydanın birbirini götürerek sıfır sonucunu vermelerini ifade eder. Diğer taraftan Parsons'a [31] göre gücün sifir toplamlı bir oyun olmaması da mümkündür. Buradan hareketle, diğerine rağmen kazanmak yerine ortaklık yoluyla toplam kaynakları artırmak her bir çıar grubunun elde edeceği kazancı 
artıracak böylece tüm kaynaklar artarak çatışmalar azalacaktır yorumunu yapmak mümkündür. $\mathrm{Bu}$ açıdan Parsons'un [31] görüşünün yeni bilimsel anlayış ile daha fazla örtüştüğü bu sebeple uygulamada olmasa bile teoride daha fazla kabul gördüğü söylenebilir.

Örgütsel bağlam-güç okulu ilişkisine, örgütsel liderlik perspektifinden bakıldığında, De Wit ve Meyer'e [2] göre stratejinin örgütte uygulanması liderin gücü ölçüsünde mümkündür. Strateji liderin ve/veya üst yönetimin kararlarını yansıtır. Lider hem pozisyondan kaynaklanan formal gücünü hem de kişiliğinden kaynaklanan karizma, deneyim, ikna etme gücünü [6] kullanarak astlarını etkilemeli ve kendisini izlemelerini sağlayabilmelidir. Politikalar, değişime direnç, kültür, yeni bilgileri öğrenme zorluğu gibi örgütsel dinamikler her zaman mevcuttur ancak güçlü lider bu zorlukları aşmayı bilir. Buna göre liderin, örgütün iç ve dış çevresini analiz ederken ve stratejiyi geliştirirken tek bir doğrunun olduğu görüşüyle, katı kurallar ve genellemelerle değil, her sistemin kendine özgü özelliklere sahip olduğu bilinciyle örgütün ortamına uygun olarak çeşitlilik gösteren bir yaklaşım içinde hareket ettiği oranda gücü elde edip sürdüreceği öne sürülebilir. Lider proaktif hareket gücüne sahip oldukça, örgütsel davranış üzerinde kontrol kazanma şansı artar. Örgütte var olan politik yapıyı ve güçlü kişi ve grupları doğru analiz edebilir ve çalışanların kalplerini ve kafalarını kazanabilirse örgüt kültürünü değiştirerek yeni yönlere yöneltebilir. $\mathrm{Bu}$ durumda örgütsel dinamikler önemli olsa da liderin gücü örgütsel bağlamı şekillendirmede etkili bir karşı baskı aracı olabilir [2]. Ayrıca lider, kontrolü elinde tutmak koşuluyla yaratıcı çatışmalar üreten bir politik ortamı destekleyerek örgütün başarısını artırabilir. Nonaka [48] bir örgütün sürekli gelişme ve değişim için örgütteki birimler arasında özgürlük sağlamanın ve aralarında yaratıcı çatışmalar oluşturmanın önemli olduğunu vurgulamaktadır.

Örgütsel bağlam örgütsel dinamikler perspektifinden değerlendirildiğinde, bu perspektifin yeni bilimsel paradigma ile örtüştüğü görülmektedir. Yeni bilimsel paradigmaya göre nedensellik ilkesine dayalı sebep sonuç ilişkileri sosyal olaylarda kaybolmakta, uzun dönemli planların sonuçları kestirilememektedir. İnsanın merkezde olduğu örgütlerde farklı ve çeşitli algılamalar söz konusu olduğundan olay ve olgulara ilişkin katı kurallar ve genellemeler oluşturulamamaktadır. Bu anlayışa paralel olarak Fahey [49], stratejik süreçte bireylerin hiyerarşik pozisyonlarının değil, sosyal ilişkilerinin yansımalarının görüldüğünü, stratejik aktivitenin bireyler ve işbirliği grupları arasındaki karşılıklı etkileşimin ifadesi olduğunu öne sürmektedir.

Güç okulu çerçevesinden örgütsel dinamikler perspektifine göre strateji örgütteki baskın politik grubun isteği doğrultusunda alınan kararları içerdiği ölçüde uygulanabilir olacaktır. Papadakis ve diğerleri [50] CEO ve üst yönetimin politik aktiviteleri etkilemede etkisiz olduklarını bulmuşlardır. CEO'ların politik aktiviteleri etkilemekte başarısız olmaları, stratejiyi oluştursalar da uygulamada örgütü bu strateji yönünde ilerletmede sorunlarla karşılaşacağını gösterir. Özetle örgütte süregelen politik ve kültürel ortam liderin örgütü dilediği yöne götürmesine engel oluşturabilmektedir. Dolayısıyla örgütsel dinamikler perspektifi stratejik süreçte liderin rolünün değişkenliği sınırlı tutarak stratejinin örgütün alt kademelerinden yukarıya doğru kendiliğinden gelişmesini sağlayacak bir ortam oluşturmak, politik ortamda bir rehber ve yargıç olarak davranmak olduğunu ileri sürmektedir.

Örgütsel bağlamı, örgütsel liderlik ve örgütsel dinamikler perspektiflerinden değerlendirirken, kültürel farklılıkları da dikkate almak faydalı olacaktır. Hofstede'ye [51] göre belirsizlikten kaçınma seviyesi yüksek olan toplumlarda işlerin kontrol altında olduğunu bilmek önemlidir. Buradan hareketle örgütsel liderlik perspektifinin strateji oluşturmada daha baskın olacağını söylemek mümkün olabilir. Lider belirsizliği ortadan kaldırdığı ölçüde güç kazanacak ve daha az dirençle karşılaşarak stratejik değişimi gerçekleştirebilecektir. Yine Hofstede'ye göre belirsizlik toleransı yüksek olan toplumlarda ise belirsiz durumlardan endişelenme oranı düşüktür. İşlerin kaotik koşullar altında yürümesi örgütteki kişileri fazla tedirgin etmez. Bu tür toplumlarda stratejik süreçte örgütsel dinamikler perspektifinin etkin olması daha muhtemeldir denilebilir.

\section{SONUÇ}

$\mathrm{Bu}$ çalışmada stratejik süreçlerde örgütsel bağlamın yeri güç okulu açısından değerlendirilmiştir. Örgütsel bağlam strateji oluşumu ve uygulanmasına bakış açılarını gösteren kontrol ve kaos paradoksları temelinde ele alınmıştır. Buna göre örgütsel bağlamda stratejik süreç, kontrolü yansıtan örgütsel liderlik perspektifi ile kaosu yansıtan örgütsel dinamikler perspektifleri ekseninde ele alınmış ve güç okulu ile ilişkisi değerlendirilmiştir.

Sonuç olarak stratejik süreçte kontrol ve kaos paradoksunun bütünüyle birbirinden ayrı tutulamayacağı ancak güç okuluna yeni bilimsel yaklaşımlar açısından örgütsel bağlamda stratejik sürecin kaos paradoksu ile daha yakından ilişkili olduğu ileri sürülebilir. Çevrenin kaotik doğasına uyum sağlamak isteyen bir örgütün kendisini her zaman dengesizlik durumunda tutmasının önemli olduğunu söylemek mümkündür. Günümüz hızlı değişen çevresel koşullarında stratejinin başarısı durağan olan örgütsel liderlik ile durağan olmayan örgütsel dinamikler perspektifleri arasındaki dengesizlikte yatmaktadır. Değişen koşullara uygun olarak sistem ve yapılarını bu iki durum arasında değiştirebilen liderler başarıya daha yakındırlar. $\mathrm{Bu}$ da liderin ana planlayıcı rolü ile örgüt içi politikalar arasında bir hakim ve rehber 
rolünü koşulların gerektirdiği oranlarda birlikte yürütebilecek güce sahip olmasıyla mümkün görünmektedir.

Güç ile ilgili Mills [30] ve Parson'un [31] kabul ettiği iki zıt varsayımdan Parsons'un varsayımının yeni bilimsel anlayışla teorik olarak daha fazla uyuştuğu görülmektedir. Buna göre gücün, bir tarafin kazanması diğer tarafin kaybetmesi anlamına gelen sıfır toplamlı bir oyun olduğu düşüncesinden, kaynakların genişleme kapasitesi nedeniyle herkesin kazanacağı bir oyun olduğu düşüncesine geçildiği söylenebilir. Ancak teorik açıdan böyle bir değişim söz konusu olsa da uygulamada hangi görüşün geçerli olduğu cevaplanması gereken bir sorudur. İleride yapılacak çalışmalarda teoride yaşanan fikir değişiminin uygulamada da geçerli olup olmadığının araştırılması oldukça faydalı olacaktır.

\section{YARARLANILAN KAYNAKLAR}

[1] Pettigrew, A.M. (1987). Context and Action in the Transformation of the Firm. Journal of Management Studies, 24(6), 649-670.

[2] De Wit, B. \& Meyer, R. (1998). Strategy, Process, Content, Context: An International Perspective. London: International Thomson Business Press.

[3] Moorhead, G. \& Griffin, R.W. (1998). Organizational Behavior: Managing People and Organization. 5th Ed. Boston: Houghton Mifflin.

[4] Grimes, A.J. (1978). Authority, Power, Influence and Social Control: A Theoretical Synthesis. Academy of Management Review, 3(4), 724-735.

[5] Emerson, R.M. (1962). Power-Dependence Relations. American Sociological Review, 27(1), 31-41.

[6] Pfeffer, J. (1999). Güç Merkezli Yönetim: Örgütlerde Politika ve Nüfuz. İstanbul: Boyner Holding Yayınları.

[7] Krackhardt, D. (1990). Assessing the Political Landscape: Structure, Cognition, and Power in Organizations. Administrative Science Quarterly, 35(2), 342-369

[8] Valesquez, M.G. (2002). Business Ethics. 5th Ed. New York: Prentice Hall.

[9] Mintzberg, H.; Ahlstrand, B. \& Lampel, J. (1998). Strategy Safari. New York: The Free Press.

[10] Narayanan, V.K. \& Fahey, L. (1982). The Micro-Politics of Strategy Formulation. Academy of Management Review, 7(1), 25-34.

[11] Eisenhardt, K.M. \& Zbaracki, M.J. (1992). Strategic Decision Making. Strategic Management Journal, 13(1), 17-37.
[12] Green, D.D. (2007). Leading a Postmodern Workforce. Academy of Strategic Management Journal, 6(1), 15-26.

[13] Rouleau, L. \& Seguin, F. (1995). Strategy and Organization Theories: Common Forms of Discourse. Journal of Management Studies, 32(1), 101-117.

[14] Schermenhorns, H. (2004). Core Concepts of Organizational Behavior. Osborn: JohnWiley \& Sons Pub.

[15] Shetty, Y.K. (1978). Managerial Power and Organizational Effectiveness: A Contingency Analysis. Journal of Management Studies, 15(2), 176-186.

[16] Mann, S. (1995). Politics and Power in Organizations: Why Women Lose Out. Leadership \& Organization Development Journal, 16(2), 9-15.

[17] Greenberg, B. (1997). Behavior in Organizations 6th Ed. New Jersey: Prentice-Hall Pub.

[18] Robbins, S.P. (2003). Organizational Behavior. 10th Ed. New Jersey: Prentice Hall Pub.

[19] Allen, R.W.; Madison, D.L.; Porter, L.W.; Renwick, P.A. \& Mayes, B.T. (1979). Organizational Politics: Tactics and Characteristics of Its Actors. California Management Review, 22(1), 77-83.

[20] Oliver, C. \& Holzinger, I. (2008). The Effectiveness Of Strategic Political Management: A Dynamic Capabilities Framework. Academy of Management Review, 33(2), 496520.

[21] Pfeffer, J. \& Salancik, G.R. (1974). The Bases and Use of Power in Organizational Decision Making: The Case of a University. Administrative Science Quarterly, 19(4), 453473.

[22] Mintzberg, H. (1984). Power and Organization Life Cycles. The Academy of Management Review, 9(2), 207224.

[23] Salancik, G.R. \& Pfeffer, J. (1988). Who Gets Power and How They Hold on to it: A Strategic-Contingency Model of Power. (Ed.: Leavitt, H.J.; Pondy, L.R. \& Boje, D.M.). Readings in Managerial Psychology. London: University of Chicago Press, 348.

[24] Hickson, D.J. \& Hinigs, C.R. \& Lee, C.A. \& Schneck, R.S. \& Pennings, J.M. (1971). A Strategic Contingencies Theory of Intraorganizational Power. Administrative Science Quarterly, 16(2), 216-229.

[25] Pfeffer, J. \& Salancik, G.R. (1978). The External Control of Organizations: A Resource Dependence Perspective. New York: Harper ve Row.

[26] Samuel, Y. (2005). The Political Agenda of Organizations. London: Transaction Pub. 
[27] Mackenzie, K.D. (1986). Virtual Positions and Power. Management Science. 32(5), 622-642.

[28] Bakoğlu, R. (2003). Kaynak Bazlı Firma Teorisi Kapsamında Değișen Rekabet Avantajı Kavram ve Anlayışı. Ístanbul Üniversitesi Iş̧letme Fakültesi Dergisi. 32(1), 65-76.

[29] Oliver, C. (1997). Sustainable Competitive Advantage: Combining Institutional and Resource-Based Views. Strategic Management Journal. 18(9), 697-713.

[30] Mills, C.W. (1956). The Power Elite. New York: Oxford University Press.

[31] Parsons, T. (1964). The Social System. Glence, IL: Free Press.

[32] Pfeffer, J. (1981). Power in Organizations. Marshfield: Pitman Pub.

[33] March, J.G. (1962). The Business Firm As a Political Coalition. Journal of Politics, 24(4), 662-678.

[34] Eisenhardt, K.M. (2000). Paradox, Spirals, Ambivalence: The New Language of Change and Pluralism. Academy of Management Review, 25(4), 703-705.

[35] Flamholtz, E.G.; Das, T. \& Tsui, A.S. (1985). Toward an Integrative Framework of Organizational Control. Accounting Organizations and Society, 10(1), 35-50.

[36] Johnson, G. (1998). Rethinking Incrementalism. (Ed.: De Wit, B. \& Meyer, R.). Strategy: Process, Content, Context: An International Perspective. London: International Thomson Business Press.

[37] Christensen, R.; Andrews, K.; Bower, J. ; Hamermesh, R. \& Porter, M. (1998) The CEO: Leadership. (Ed.: De Wit, B. \& Meyer, R.). Strategy: Process, Content, Context: An International Perspective. London: International Thomson Business Press.

[38] Yıldırım, A. \& Şimşek, H. (2005). Sosyal Bilimlerde Nitel Araştırma Yöntemleri. Ankara: Seçkin Yayıncılık.

[39] Stacey, R. (1998). Strategy as Order Emerging from Chaos. (Ed.: De Wit, B. \& Meyer, R.). Strategy: Process, Content, Context: An International Perspective. London: International Thomson Business Press.

[40] Gleick, J. (1995). Kaos. Ankara: Tübitak Popüler Bilim Kitapları.

[41] Levy, D. (1994). Chaos Theory and Strategy: Theory, Application, and Managerial Implications. Strategic Management Journal, 15(3), 167-178.

[42] McCaskey, M. (1998). Conceptual Mapping. (Ed.: De Wit, B. \& Meyer, R.). Strategy: Process, Content, Context: An International Perspective. London: International Thomson Business Press.
[43] Latif, H. (2002). Kaotik Ortamda Yönetim Stratejik Boyutuyla Modern Yönetim Yaklaşımları. İstanbul: Beta Basım Yayım Dağıtım A.Ş.

[44] Bourgeois, L.J. \& Broadwin, D. (1998). Linking Planning and Implementation. (Ed.: De Wit, B. \& Meyer, R.). Strategy: Process, Content, Context: An International Perspective. London: International Thomson Business Press.

[45] Hart, S.L. (1992). An Integrative Framework for StrategyMaking Processes. The Academy of Management Review, 17(2), 327-351.

[46] Chandler, A. (1962). Strategy and Structure. Cambridge, MA: MIT Press.

[47] Mintzberg, H. (1978). Patterns in Strategy Formation. Management Science, 24(9), 934-948.

[48] Nonaka, I. (1988). Creating Organizational Order Out of Chaos: Self-Renewal in Japanese Firms. California Management Review, 30(3), 57-73.

[49] Fahey, L. (1981). On Strategic Management Decision Processes. Strategic Management Journal, 2(1), 43-60.

[50] Papadakis, V.M.; Lioukas, S.; Chambers, D. (1998). Strategic Decision-Making Processes: The Role of Management and Context. Strategic Management Journal. 19(2), 115-147.

[51] Hofstede, G. (1984). Culture's Consequences: International Differences in Work-related Values. London: Sage Publications.

\section{Refika BAKOĞLU DELİORMAN}

(refika@marmara.edu.tr) is an Associate Professor of Management and Organization in the Department of Business Administration at the Faculty of Economics and Administrative Sciences, Marmara University. Her research interests are strategic management and all international business related issues.

Mukaddes BAHAR (mukaddesbahar@yahoo.com) is a $\mathrm{PhD}$ student of Management and Organization in the Department of Business Administration at the Faculty of Economics and Administrative Sciences, Marmara University. Her research interests are human resources management, organizational behavior and knowledge management. 